\title{
Pengaruh Lipatan Baja JIS SUP 9 dan 0,5 CCrMnSi Terhadap Nilai Kekerasan, Struktur Mikro dan Pattern pada Permukaan Pisau
}

\author{
Luthfan N Lamoni dan Suwarno \\ Departemen Teknik Mesin, Fakultas Teknologi Industri, \\ Institut Teknologi Sepuluh Nopember (ITS) Surabaya \\ e-mail: warnoise@gmail.com
}

\begin{abstract}
Abstrak-Pisau sebagai salah satu jenis alat potong terus berkembang seiring dengan semakin beragamnya kebutuhan manusia. Kualitas pisau yang tinggi ditinjau dari segi kekerasan, ketangguhan, maupun ketajamannya ditentukan oleh bahan dan proses pembuatannya. Penelitian ini bertujuan untuk meningkatkan kualitas pisau tempa manual tradisional yang ada di indonesia. Dengan memanfaatkan metode penempaan welded forging. Pada penelitian ini digunakan lembaran plat baja JIS SUP 9 dan baja cor 0,5CCrMnSi yang disusun membentuk 2 benda kerja yaitu $B 1$ dan $B 2$ dengan dimensi 75 x 30 x 15 mm yang terdiri dari 7 lapisan. Benda kerja kemudian ditempa secara manual dengan beberapa tahap penempaan. Pada setiap tahap terjadi beberapa siklus yang membentuk dimensi ketebalan akhir $3 \mathrm{~mm}$. Pada penelitian ini didapatkan nilai kekerasan pada penampang pisau B1 nilai kekerasannya sebesar 351 HV. Pada permukaan pisau B1 nilai kekerasannya sebesar $339,3 \mathrm{HV}$. Sedangkan pada penampang pisau B2 nilai kekerasannya sebesar 434,9 HV, pada permukaannya sebesar $383,8 \mathrm{HV}$. Hasil pengamatan struktur mikro menunjukan ukuran butir yang terbentuk setelah proses penempaan lebih kecil dan halus. Batas2 antara material yang berbeda tetap terlihat dan tidak berdifusi antara satu dengan yang lainnya. Fase yang terbentuk adalah pearlite, ferrtie, dan martensite tempered.
\end{abstract}

Kata Kunci- Pisau, Damaskus, Welded Forging, Penempaan.

\section{PENDAHULUAN}

$\mathrm{P}_{\mathrm{j}}^{\mathrm{s}}$ ISAU sebagai salah satu jenis alat potong yang sering kita jumpai dalam kehidupan sehari hari, terus mengalami perkembangan seiring dengan berkembangnya teknologi. Pisau dengan kualitas yang tinggi, baik dari segi kekerasan, ketangguhan, maupun ketajamannya menjadi penting seiring dengan semakin beragamnya kebutuhan manusia. Pisau dengan kualitas yang tinggi, baik dari segi kekerasan, ketangguhan, maupun ketajamannya menjadi penting seiring dengan semakin beragamnya kebutuhan manusia.

Pada abad pertengahan, terdapat sebuah alat potong yang disebut pedang/pisau damaskus. Penelitian terdahulu terhadap bahan pisau/pedang damaskus peninggalan abad 17 (genuine damascus), menunjukan bahwa unsur-unsur penyusun pisau damaskus adalah 1,60\% C, 0,56\% Mn, 0,17\% P, $0,02 \%$ S, $0,048 \%$ Si, 0,012\% Ni, 0,048\% Cu, 0,01\% V, dan 0,002\% Ti [1]. Dengan nilai kekerasan 62-67 HRC [2]. Baja damaskus memiliki pola damask, yang dipengaruhi oleh proses penempaan dan unsur-unsur pengotor seperti V, Mo, $\mathrm{Mn}, \mathrm{Nb}$.

Usaha menciptakan kembali pisau atau pedang damaskus telah dilakukan oleh banyak peneliti. Diantaranya adalah Verhoeven, dan Wadsworth - Sherby. Verhoeven membuat kembali pisau yang mendekati genuine damascus dengan metode penempaan manual oleh pande besi pada temperatur tempa $1175^{\circ} \mathrm{C}-825^{\circ} \mathrm{C}$ dan rasio penempaan 9 menggunakan ingot yang dibuat dengan komposisi kimia mendekati genuine damascus. Sedangkan Wadsworth dan Sherby meneliti sifat dari ultra high carbon steel setelah proses rolling. Dimana terbentuk pola yang hampir mirip dengan pola damask. Berdasarkan hal ini Wadsworth dan Sherby menggunakan metode welded forging dalam menciptakan pisau damaskus dengan pola damask pattern.

Penelitian terkait pengaruh kekerasan material pisau tempa manual dengan proses perlakuan panas menunjukan bahwa nilai kekerasan tertinggi baja JIS SUP 9 yang ditempa secara manual dan diberikan perlakuan panas, dimiliki oleh baja JIS SUP 9 dengan proses pengerasan pada furnace. Dengan nilai kekerasan yang didapatkan adalah sebesar 62 HRC pada permukaannya, dan 60,2 HRC pada penampang[3]. Penelitian terhadap bahan baja paduan rendah dengan komposisi kimia 0,5\% C; 1,95\% Si; 1,7\% Mn; 0,3\% Ni; 1,1\% Cr; 0,007\% V; 0,01\% Mo memiliki karakteristik yang cukup baik setelah ditempa. Yaitu dengan hilangnya porositas serta nilai kekerasan sebesar 62,44 HRC setelah proses quenching, 57,67 HRC setelah proses normalizing, dan 38,67 HRC setelah proses annealing [4]. Ketangguhan, kekerasan dan tingginya unsur pengotor pada baja paduan dan baja JIS SUP 9 ini mampu dimanfaatkan sebagai bahan pisau tempa. Sebagai upaya meningkatkan kualitas pisau yang dihasilkan oleh pandai besi tradisional di indonesia, perlu dilakukan penelitian tentang pisau.

Penelitian yang dilakukan menggunakan bahan baja paduan rendah 0,5CCrMnSi dan baja JIS SUP 9 dengan variasi jumlah lipatan pada proses penempaan. Untuk mengamati pengaruhnya terhadap pembentukan pola damask, kekerasan dan struktur mikro yang dihasilkan.

Terbatasnya pengetahuan mengenai proses pembuatan welded damascus blade dengan bahan material JIS SUP 9 dan baja cor 0,5CCrMnSi menggunakan metode penempaan manual. Sehingga belum banyak pande besi tradisional di indonesia yang menggunakan metode dan bahan material serupa.

Dalam penelitian ini akan di evaluasi pengaruh variasi jumlah lipatan pada proses penempaan manual, menggunakan bahan baja JIS SUP 9 dan baja cor 0,5CCrMnSi, terhadap nilai kekerasan, struktur mikro, dan pola pada permukaan pisau yang terbentuk.

Penelitian ini bertujuan untuk mengetahui pengaruh jumlah lipatan pada proses penempaan manual, terhadap nilai kekerasan, dan struktur mikro. Dengan mengkombinasikan baja JIS SUP 9 dan baja 0,5CCrMnSi sebagai bahan pisau welded damascus. 


\section{TINJAUAN PUSTAKA}

\section{A. Penelitian Terdahulu}

Penelitian mengenai pisau damaskus terus dilakukan sebagai upaya dalam menemukan kembali teknologi pembuatannya yang hilang. Peneliti terdahulu memanfaatkan pisau atau pedang damaskus peninggalan abad pertengahan sebagai bahan penelitian mereka guna menemukan kunci dari ketajamannya. Beberapa karakteristik yang ditunjukan oleh pisau dan pedang damaskus peninggalan abad pertengahan atau yang biasa disebut "genuine damascus" diantaranya adalah seluruh "genuine damascus" yang ada memiliki “damask pattern”[1].

Penelitian tentang pengaruh unsur unsur pengotor pada ingot dalam pembentukan pola damask telah dilakukan oleh [14]. Penelitian ini menggunakan forging manual oleh pande besi profesional. Bahan yang digunakan pada percobaan ini adalah logam Sorel sebagai ingot dengan kandungan karbon berkisar 3,9 - 4,7\% C dan 0,003 - 0,014\% V. Penambahan 0,003\% V, Mo, Mn, Nb dalam persentase sedikit mengakibatkan terjadi band karbida pada ingot. Pengujian menggunakan Electron probe microanalysis (EPMA) pada ingot logam Sorel menunjukkan terjadi microsegregated pada interdendit yang lebih terkonsentrasi. Hal ini disebabkan oleh penambahan unsur-unsur V, Mo, Mn, dan Nb kurang dari $0.02 \%$.

Dalam menggunakan metode penempaan manual dalam membentuk pisau welded damascus, jumlah layer yang digunakan mempengaruhi proses difusi dari karbon antara kedua jenis layer yang digunakan. Semakin banyak jumlah layer, proses difusi antara karbonnya membutuhkan waktu yang semakin sebentar, selain itu temperature yang tinggi juga mempercepat difusi antara karbonnya.

\section{B. Proses Tempa}

Penempaan atau forging merupakan proses pengolahan logam yang sudah dikenal sejak lama. Proses ini merupakan proses pembentukan logam dengan mendeformasi plastis suatu bahan. Pada umumnya proses penempaan dilakukan dengan memberikan beban secara berulang ulang membentuk suatu siklus hingga bahan logam tersebut terbentuk seperti yang diinginkan. Penempaan dapat dilakukan secara manual dengan menggunakan beban dari tenaga manusia menggunakan palu, ataupun secara otomatis dengan dengan beban dari mesin dan menggunakan cetakan. Selain merubah bentuk proses penempaan juga menghaluskan struktur butir dan dapat mengurangi proses permesinan.

Dalam proses penempaan terdapat dua macam metode penempaan, yaitu pengerjaan dingin dan pengerjaan panas. Metode pengerjaan panas dilakukan dengan cara bahan dipanaskan terlebih dahulu hingga mencapai temperatur sekitar 0,75 $T_{m}$, kemudian dilakukan proses penempaan pada temperatur 0,6 $T_{m}$ hingga $0,5 T_{m}$. Metode ini yang biasa digunakan oleh pande besi tradisional [5].

Pande besi tradisional melakukan pengontrolan temperatur secara manual berdasarkan warna dari baja dan api yang dihasilkan. Secara tidak langsung warna dari api menunjukan temperaturnya, seperti pada Tabel 1 dibawah ini. Warna api atau baja yang digunakan ketika melakukan penempaan pada umumnya berwarna cherry red atau pada temperatur tempa sekitar $800^{\circ} \mathrm{C}$ [6].

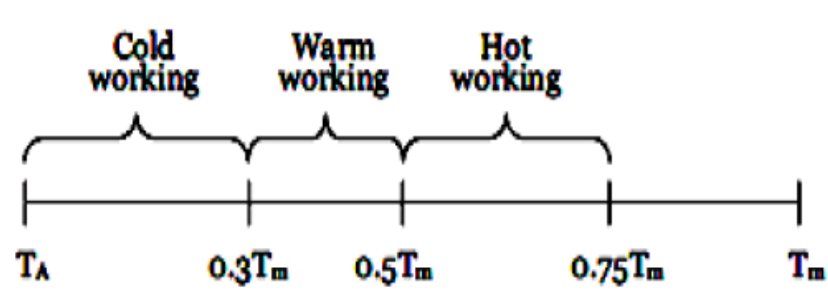

Gambar 1. Batas Temperature Pengerjaan Panas[5].

Tabel 1.

Variasi Warna dan Temperratur Pada Api[4]

\begin{tabular}{cc}
\hline \hline Temperature $\left({ }^{\circ} \mathbf{F} /{ }^{\circ} \mathbf{C}\right)$ & Warna \\
\hline $1200^{\circ} \mathrm{F} / 648^{\circ} \mathrm{C}$ & Dull red \\
$1400^{\circ} \mathrm{F} / 760^{\circ} \mathrm{C}$ & Red \\
$1500^{\circ} \mathrm{F} / 815^{\circ} \mathrm{C}$ & Cherry red \\
$1600^{\circ} \mathrm{F} / 871^{\circ} \mathrm{C}$ & Full cherry red \\
$1800^{\circ} \mathrm{F} / 982^{\circ} \mathrm{C}$ & Orange \\
$1900^{\circ} \mathrm{F} / 1037^{\circ} \mathrm{C}$ & Orange yellow \\
$2000^{\circ} \mathrm{F} / 1093^{\circ} \mathrm{C}$ & Yellow \\
$2200^{\circ} \mathrm{F} / 1204^{\circ} \mathrm{C}$ & Full yellow \\
$2400^{\circ} \mathrm{F} / 1315^{\circ} \mathrm{C}$ & Light yellow \\
\hline \hline
\end{tabular}

\section{METODOLOGI PENELITIAN}

A. Material

Tabel 2.

Bahan Penelitian dan Komposisi Kimia

\begin{tabular}{ccccccccccc}
\hline \hline \multirow{2}{*}{ Bahan } & \multicolumn{10}{c}{ Unsur-unsur (\%berat) } \\
\cline { 2 - 11 } & C & Si & Mn & P & S & Ni & Cr & Mo & Cu & V \\
\hline 0,5CCr & 0,5 & 1,7 & 1,9 & 0,0 & 0,0 & 0,0 & 1,0 & 0,0 & 0,0 & 0,0 \\
MnSi & 43 & 87 & 97 & 22 & 10 & 70 & 53 & 16 & 50 & 12 \\
JIS & 0,6 & 0,2 & 0,8 & 0,0 & 0,0 & 0,0 & 0,8 & 0,0 & 0,0 & 0,0 \\
SUP 9 & 27 & 43 & 53 & 12 & 09 & 36 & 97 & 13 & 29 & 08 \\
\hline \hline
\end{tabular}

Material-material yang digunakan dalam penelitian ini ditunjukkan pada Tabel 2. Masing masing jenis material dibentuk menjadi potongan lembaran plat dengan dimensi panjang yaitu 75 x 15 x 4,28 mm seperti ditunjukkan pada Gambar 2.

Setelah dibentuk menjadi lembaran plat, kombinasi bahan baja 0,5CCrMnSi dengan baja JIS SUP 9 disusun menjadi susunan lapisan yang membentuk benda kerja billet dengan dimensi total 75 × 15 × 30 mm seperti pada Gambar 3 dibawah ini dengan jumlah variasi susunan layer 4 baja JIS SUP 9 dan 3 baja 0,5 CCrMnSi.

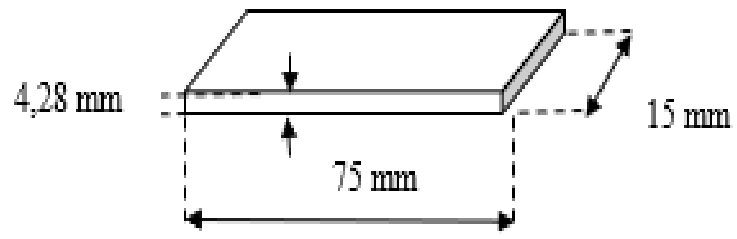

Gambar 2. Skema dimensi bahan lembaran plat dengan dimensi 75 x 15 x $4,28 \mathrm{~mm}$.

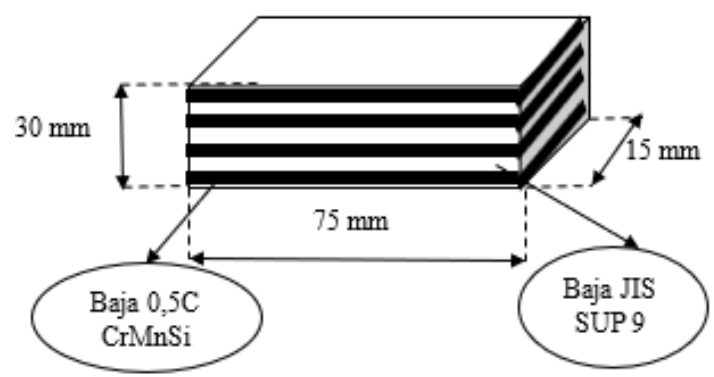

Gambar 3. Contoh susunan layer yang membentuk benda kerja. 


\section{B. Proses Penempaan}

Penempaan benda kerja dilakukan secara manual oleh operator yang sama. Penempaan dilakukan dengan temperatur tempa antara $50^{\circ} \mathrm{C}$ sampai $250^{\circ} \mathrm{C}$ diatas $\mathrm{A}_{3}$. Temperatur $140^{\circ} \mathrm{C}$ diatas $\mathrm{A}_{\mathrm{cm}}$ dengan waktu tahan 0.5-1.5 menit adalah nilai yang cukup optimum. Proses penempaan terbagi kedalam 3 tahap, dengan siklus tempa seperti pada Tabel 3. Dimensi akhir pisau yang dihasilkan setelah proses penempaan memiliki tebal $3 \mathrm{~mm}$. Pada benda kerja billet B2 dilakukan pelipatan pada tahap pertama hingga 5 kali. Proses penempaan dilakukan dengan faktor reduksi penempaan sebesar 9 pada ketebalan, serta faktor penempaan 3 pada lebar dan panjang.

Tabel 3.

Siklus Penempaan Pisau

\begin{tabular}{cccccc}
\hline $\begin{array}{c}\text { Forging } \\
\text { stage }\end{array}$ & $\begin{array}{c}\text { Benda } \\
\text { kerja }\end{array}$ & Temp. range & $\begin{array}{c}\text { Tebal } \\
\text { awal (mm) }\end{array}$ & $\begin{array}{c}\text { Tebal } \\
\text { akhir (mm) }\end{array}$ & $\begin{array}{c}\text { \% Red. } \\
\text { Area }\end{array}$ \\
\hline 1 & B1 & $1000=>750^{\circ} \mathrm{C}$ & 30 & 23 & $23,3 \%$ \\
& B2 & & 30 & 23 & \\
2 & B1 & \multirow{2}{*}{$800=>700^{\circ} \mathrm{C}$} & 23 & 16 & $30 \%$ \\
& B2 & & 23 & 16 & \\
3 & B1 & \multirow{2}{*}{$700=>500^{\circ} \mathrm{C}$} & 16 & 3 & $81,25 \%$ \\
\hline \hline
\end{tabular}

Setelah proses penempaan dilakukan, pisau yang terbentuk kemudian dihaluskan dengan menggunakan grinder. Kemudian untuk memperjelas pola yang terbentuk pada permukaan, permukaan pisau di etsa menggunakan larutan nital.

\section{HASIL PENELITIAN DAN PEMBAHASAN}

Hasil penelitian mengenai pengaruh jumlah lipatan baja pada pisau tempa manual terhadap kekerasan, struktur mikro, dan pattern pada permukaan diperoleh data berupa angka (nilai), grafik, dan Gambar. Pengujian yang dilakukan meliputi uji komposisi kimia, kekerasan, pengamatan struktur mikro, serta pengamatan makro pada permukaan pisau yang terbentuk.

Setelah dilakukan proses penempaan, terbentuk 2 jenis pisau yaitu B1 dan B2 dimana pisau B1 merupakan susunan dari 7 layer kombinasi bahan, dan pisau B2 merupakan susunan dari 7 layer kombinasi bahan yang mengalami proses difusi antar layer lebih lama dan temperatur lebih tinggi. Gambar 4 (a) dan (b) dibawah merupakan pisau hasil penempaan manual.

Pada pisau hasil penempaan B1 dapat terlihat crack sepanjang garis melintang pada bagian tengah permukaan pisau. Pada pisau B2 yang terbentuk dari benda kerja B2, awalnya direncanakan untuk dapat dilakukan pelipatan sebanyak 5 kali. Namun, pada prosesnya terjadi pengurangan volume material yang cukup banyak, hal ini terjadi saat proses penyambungan antara lapisannya. Sehingga tidak dapat dilakukan pelipatan akibat material yang terlalu kecil. Oleh karena itu, terbentuk pisau dengan panjang $10 \mathrm{~cm}$, dan jumlah lapisan yang sama yaitu 7 lapisan. Hal ini terjadi diluar rencana awal yang disusun.

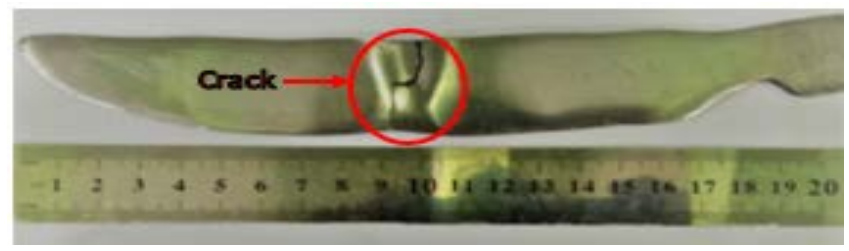

(a)

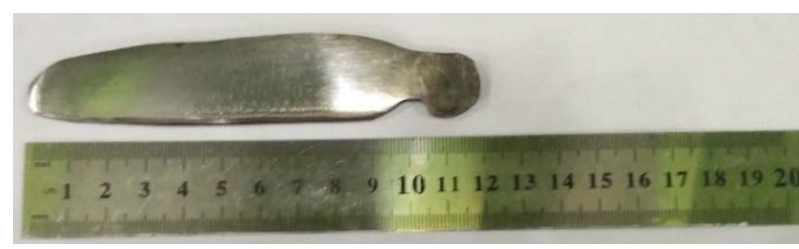

(b)

Gambar 4. Pisau tempa manual (a) Benda kerja B1 (b) Benda kerja B2.

\section{A. Pembahasan Keretakan Pisau B1}

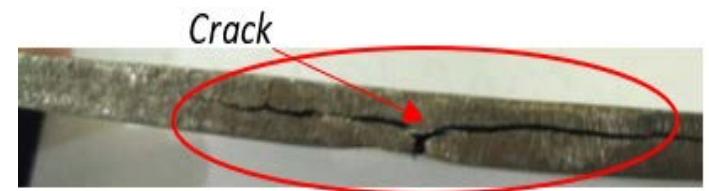

(a)

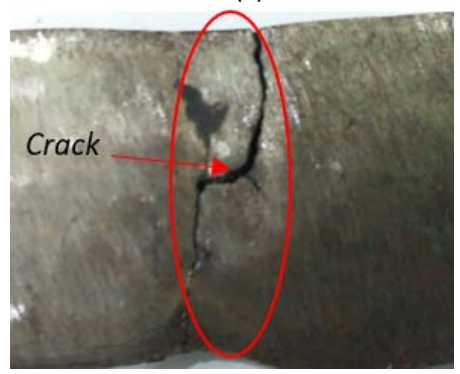

(b)

Gambar 5. Crack pada pisau B1 (a) Antara lapisan (b) Permukaan.

Pada pisau B1 terbentuk retakan di bagian tengah permukaan pisau. Keretakan pada permukaan pisau B1 berada pada sisi pisau yang bersinggungan dengan palu tempa. Keretakan terjadi pada saat memasuki tahap ke 2 proses penempaan. Dimana temperatur yang digunakan pada tahap ini adalah sebesar $800-700^{\circ} \mathrm{C}$. Penempaan yang dilakukan pada temperatur lebih rendah memerlukan energi yang lebih besar untuk membentuk pisau. Hal ini disebabkan oleh tegangan alir yang meningkat seiring dengan menurunnya temperatur pemanasan. Sehingga pada proses penempaan mulai dari tahap 1 hingga tahap 2, dimana terdapat penurunan temperatur pemanasan dan temperatur tempa, terjadi peningkatan tegangan alir yang membutuhkan energi lebih besar untuk membentuk pisau. Akibatnya material benda kerja tidak mampu menahan tegangan yang diberikan sehingga terjadi keretakan pada tahap 2 proses penempaan.

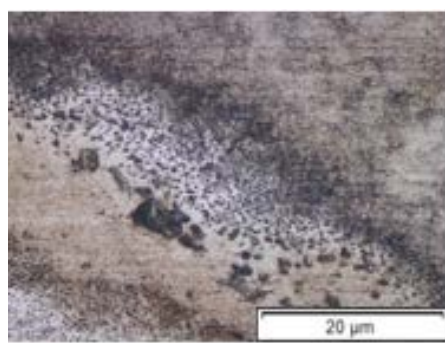

(a)

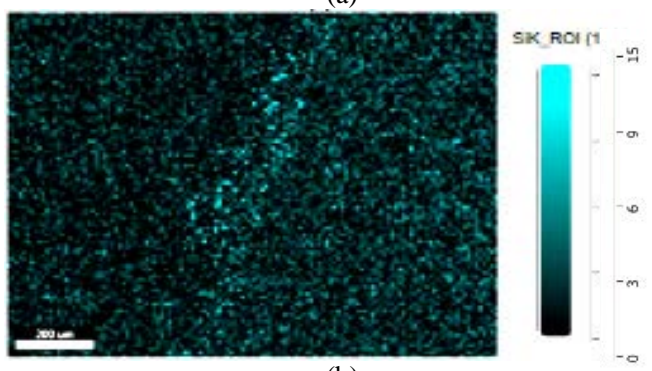

(b)

Gambar 6. Hasil pengujian struktur mikro dan SEM (a)Perbesaran 500x pada batas antara material (b)Hasil mapping EDX persebaran Silikon. 
Berdasarkan pengujian kekerasan pada daerah permukaan yang retak didapatkan bahwa nilai kekerasan pada patahan lebih tinggi dibandingkan daerah yang tidak mengalami retakan. Hasil pengujian ini dilampirkan dalam Tabel 4.

Tabel 4.

Hasil Pengujian Nilai Kekerasan Pada Retakan

\begin{tabular}{ccccccccccc}
\hline \hline \multirow{2}{*}{ Arah } & \multicolumn{10}{c}{ Titik ke - n } \\
\cline { 2 - 12 } & $\mathbf{1}$ & $\mathbf{2}$ & $\mathbf{3}$ & $\mathbf{4}$ & $\mathbf{5}$ & $\mathbf{6}$ & $\mathbf{7}$ & $\mathbf{8}$ & $\mathbf{9}$ & $\mathbf{1 0}$ \\
\hline Melintang & 370 & 298 & 323 & 329 & 678 & 564 & 612 & 354 & 247 & 470 \\
\hline \hline
\end{tabular}

Pengujian dilakukan secara melintang mulai dari material yang tidak retak, hingga pada bagian retaknya. Pada titik ke 5, 6, dan 7 merupakan bagian yang mengalami keretakan. Berdasarkan hasil pengujian ditunjukan bahwa nilai kekerasan pada bagian retak mencapai $678 \mathrm{HV}$ sedangkan bagian lainnya tidak. Hal ini menunjukan bahwa terjadi persebaran kekerasan yang tidak merata. Sehingga pada bagian retak dengan nilai kekerasan yang lebih tinggi menjadi lebih getas dan tidak mampu menahan gaya tempa yang diberikan.

Nilai kekerasan yang tinggi ini disebabkan oleh adanya penumpukan unsur penyusun butir. Pada saat proses difusi antara lapisan dari susunan kedua material ini, terjadi perpindahan unsur2 penyusun karbida. Unsur2 penyusun ini akan bergerak kearah pinggir batas butir dan material, sehingga pada batas antara materialnya akan terjadi penumpukan unsur2 tersebut. Berdasarkan hasil pengujian struktur mikro dan SEM, terlihat unsur Si yang menumpuk di batas antar material sehingga menyebabkan bagian tersebut memiliki nilai kekerasan yang lebih tinggi dan lebih getas.

\section{B. Pengamatan Pola Permukaan Pisau}

Proses penempaan pada susunan lapisan dari 2 material yang berbeda akan membentuk pola pada permukaannya. Pola ini dapat dilihat secara lebih jelas setelah dilakukan proses finishing dan dietsa menggunakan nital. Gambar 7 menunjukan pola yang terbentuk di permukaan pisau B1 maupun B2.

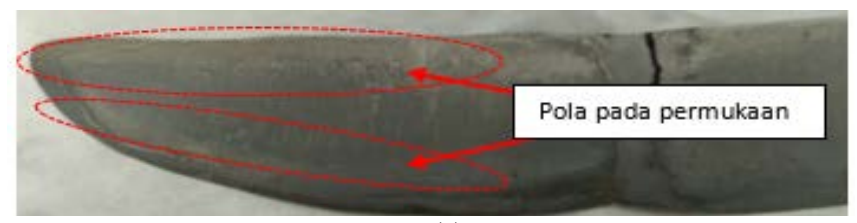

(a)

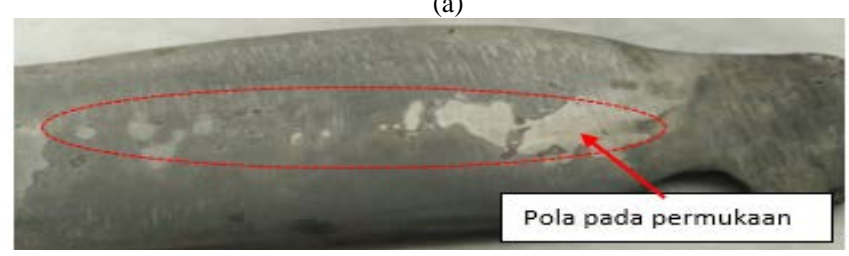

(b)

Gambar 7. Pola pada permukaan (a)Pisau B1 (b)Pisau B2.

Pola yang terbentuk pada pisau B1 dan B2 terbentuk pada salah satu sisi permukaan pisau, yaitu pada permukaan yang bersinggungan dengan palu tempa. Hal ini dapat terjadi akibat perbedaan material yang ditempa dan berdifusi menjadi satu. Meskipun antara material yang berbeda berdifusi namun masing2 tetap mempertahankan strukturnya. Batas2 antara material tersebut yang saling berdifusi dan tersebar membentuk pola pada permukaan.

Secara mikro pola tersebut tidak berbeda halnya dengan bagian yang lain. Butir2 yang terbentuk hampir sama dengan bagian lainnya. Hanya saja batas lapisan antara material JIS SUP 9 dan 0,5 CCrMnSi tetap terlihat dan mempertahankan bentuknya. Seperti pada Gambar 8.

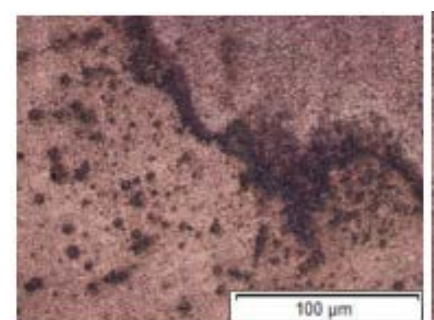

(a)

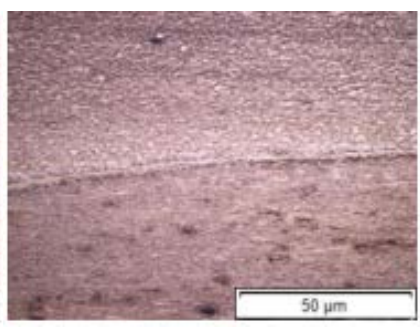

(b)
Gambar 8. Struktur mikro pola pada pisau (a) Permukaan (b) Penampang.

Tabel 5.

Hasil Pengujian Nilai Kekerasan Pada Pola

\begin{tabular}{ccccccccccc}
\hline \hline \multirow{2}{*}{ Arah } & \multicolumn{10}{c}{ Titik ke - n } \\
\cline { 2 - 11 } Melintang & $\mathbf{1}$ & $\mathbf{2}$ & $\mathbf{3}$ & $\mathbf{4}$ & $\mathbf{5}$ & $\mathbf{6}$ & $\mathbf{7}$ & $\mathbf{8}$ & $\mathbf{9}$ & $\mathbf{1 0}$ \\
\hline \hline
\end{tabular}

Pola yang terbentuk ini tidak mempengaruhi kekerasan secara khusus, hanya saja pada batas antara material tersebut memiliki nilai kekerasan yang lebih tinggi. Hal ini karena adanya penumpukan unsur2 yang berdifusi. Sehingga pada batas antara material tersebut mengalami peningkatan nilai kekerasan. Seperti pada Tabel 5.

\section{Pengujian Kekerasan}

Tabel 6.

Hasil Uji Kekerasan Bahan Awal

\begin{tabular}{|c|c|c|c|c|}
\hline \multirow{2}{*}{ Spesimen } & \multicolumn{3}{|c|}{ Nilai Kekerasan (HV) } & \multirow{2}{*}{ Rata-rata } \\
\hline & 1 & 2 & 3 & \\
\hline 0,5 CCrMnSi & 296 & 305 & 281 & 294 \\
\hline JIS SUP 9 & 242 & 231 & 238 & 237 \\
\hline
\end{tabular}

Pengujian kekerasan dilakukan pada bahan awal sebelum ditempa, dan pisau tempa manual B1 dan B2. Pada bahan awal sebelum ditempa, dilakukan pengujian kekerasan pada permukaan material baja JIS SUP 9 dan 0,5 CCrMnSi. Setelah dilakukan proses penempaan dan dihasilkan pisau B1 dan B2 dilakukan pengujian pada permukaan dan penampang dari setiap pisau. Pengujian kekerasan dilakukan pada 10 titik yang berbeda yang tersebar secara merata sepanjang permukaan maupun penampangnya.

Pengujian kekerasan pada pisau tempa manual B1 dan B2 dilakukan sepanjang permukaan dan penampang pisau. Berdasarkan data hasil pengujian yang ditunjukan pada Tabel 7 diatas, didapatkan nilai kekerasan yang tersebar disepanjang permukaan maupun penampangnya. Nilai yang didapatkan di tuangkan pada grafik persebaran kekerasan pisau pada Gambar 9.

Nilai kekerasan pada penampang baik pisau B1 maupun pisau B2 cenderung lebih tinggi dibanding permukannya. Hal ini disebabkan oleh penyusunan lapisan dilakukan secara horizontal dengan arah penempaan. Diagram alir yang dibutuhkan dalam menyatukan 2 bahan material yang berbeda hingga mengalami deformasi plastis, lebih besar dibandingkan hanya 1 jenis material saja. Oleh sebab itu, nilai kekerasan pada penampang cenderung lebih besar dibandingkan dengan permukannya.

Tabel 7.

Hasil Uji Kekerasan Pisau B1 dan B2

\begin{tabular}{cccc}
\hline \hline \multirow{2}{*}{ Material } & \multirow{2}{*}{ Titik } & \multicolumn{2}{c}{ Nilai Kekerasan (HV) } \\
\cline { 3 - 4 } & 1 & Permukaan & Penampang \\
\hline \multirow{5}{*}{ Pisau B1 } & 2 & 264 & 510 \\
& 3 & 372 & 519 \\
& 4 & 337 & 353 \\
& 5 & 366 & 346 \\
& 7 & 295 & 321 \\
& 8 & 317 & 290 \\
& 9 & 382 & 294 \\
& 9 & 331 & 236 \\
& & & 274
\end{tabular}




\begin{tabular}{cccc} 
& 10 & 346 & 367 \\
\hline \multirow{5}{*}{ Pisau B2 } & 1 & 396 & 499 \\
& 2 & 416 & 412 \\
& 3 & 361 & 484 \\
& 4 & 377 & 467 \\
& 5 & 358 & 424 \\
& 6 & 356 & 483 \\
& 7 & 336 & 349 \\
& 8 & 403 & 433 \\
& 9 & 364 & 400 \\
\hline \hline
\end{tabular}

Berdasarkan grafik persebaran nilai kekerasan pada Gambar 9, dapat dilihat kekerasan pada penampang mengalami penurunan mulai dari sisi tajam hingga sisi tumpulnya. Hal ini menunjukan bahwa sisi tajam pisau lebih keras dibandingkan dengan sisi tumpul ataupun bagian tengah. Pembentukan sisi tajam memerlukan gaya dan proses penempaan yang lebih banyak. Sehingga bagian sisi tajam pisau lebih banyak terkena gaya tempa dibandingkan sisi lainnya.

Sedangkan pada permukaan pisau persebaran kekerasan cenderung merata mulai dari sisi tajam hingga sisi tumpul. Hal ini dapat terjadi akibat gaya tempa yang diberikan merata disetiap sisinya. Butir yang terkena gaya tempa secara langsung akan pecah dan tersebar ke segala arah. Sehingga dislokasi yang terjadi pada permukaan lebih rata dibandingkan pada penampang.

Persebaran Kekerasan Pisau B1
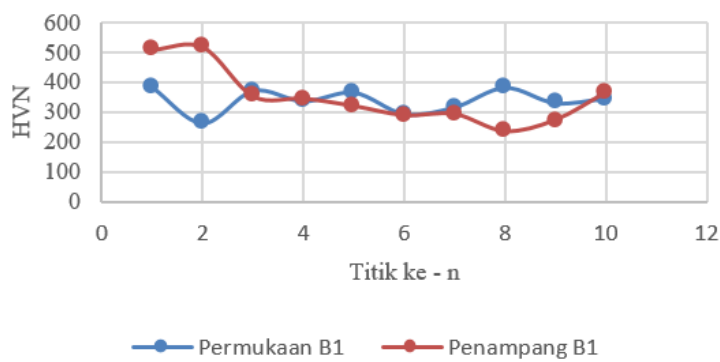

(a)

Persebaran Kekerasan Pisau B2

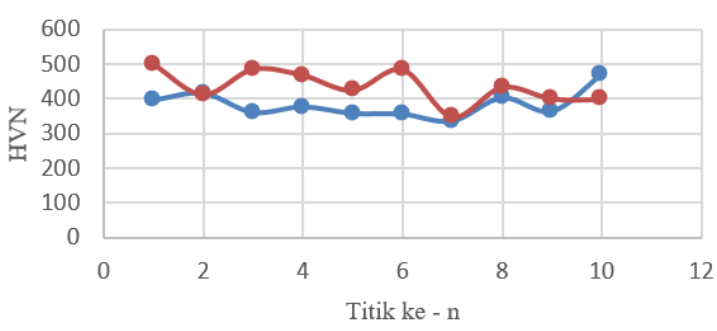

$\longrightarrow$ Permukaan B2 $\longrightarrow$ Penampang B2

(b)

Gambar 9. Grafik persebaran kekerasan (a)Pisau B1 (b)Pisau B2.

\section{Pengamatan Struktur Mikro}

Pengamatan struktur mikro pada penelitian ini dilakukan pada bahan awal dan pisau hasil penempaan. Pengamatan ini menggunakan mikroskop optik dengan pembesaran 500x dan 1000x. Struktur yang diamati adalah pada permukaan bahan awal baja JIS SUP 9 dan 0,5 CCrMnSi. Sedangkan pada pisau hasil penempaan dilakukan pengamatan pada struktur permukaan dan penampang pisau. Gambar 10 menunjukkan hasil pengamatan struktur mikro pada bahan awal dengan perbesaran 500x dan 1000x.

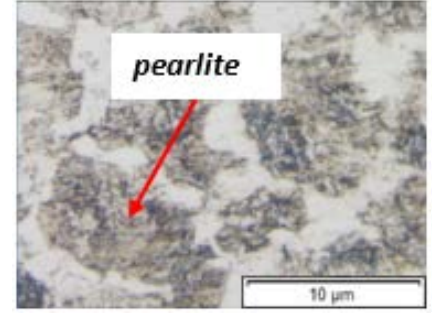

(a)

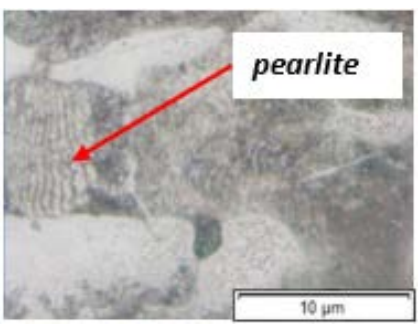

(b)
Gambar 10. Struktur mikro bahan awal (a)0,5 CCrMnSi (b)JIS SUP 9.

Pada pisau hasil penempaan manual dilakukan pengamatan sepanjang permukaan dan juga penampang. Gambar 11 dan Gambar 12 dibawah menunjukan struktur mikro pada permukaan dan juga penampang pisau B1 dan B2.

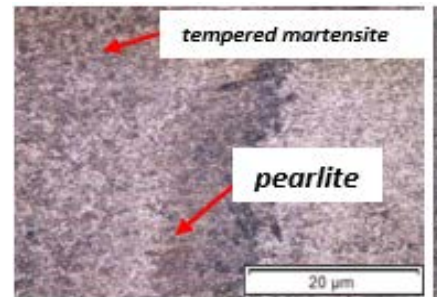

(a)

Gambar 11. Struktur mikro pisau B1

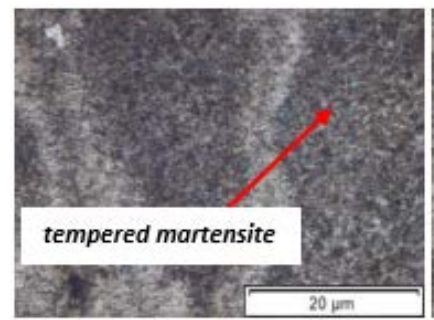

(a)

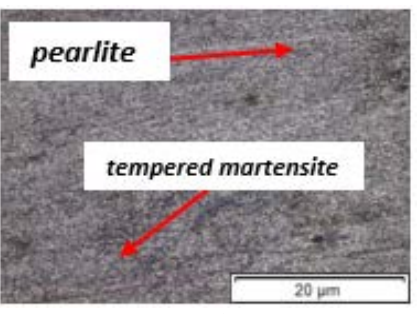

(b)

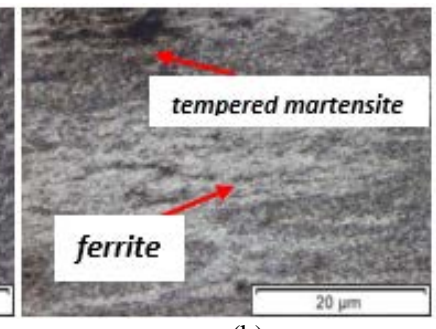

(b)
Gambar 12. Struktur mikro pisau B2 (a)Permukaan (b)Penampang.

Proses penempaan hingga membentuk pisau mengubah struktur mikro pada bahan. Berdasarkan hasil pengamatan struktur mikro bahan awal pisau memiliki fase pearlite dan ferrite dengan ukuran butir yang besar. Sedangkan setelah dilakukan proses penempaan dan terbentuk pisau B1 maupun $\mathrm{B} 2$, terlihat fase yang terbentuk adalah pearlite (berwarna gelap), ferrite (berwarna terang), dan tempered martensite (berwarna hitam dan menyebar). Pembentukan tempered martensite pada material terjadi akibat proses pemanasan dan pendinginan yang dilakukan secara berulang pada siklus tempa. Martensite yang pada awalnya terbentuk pada saat tahap penempaan 1 , dimana austenite yang terbentuk akibat proses pemanasan awal diberikan gaya tempa sehingga menghambat difusi karbida dalam membentuk kembali pearlite. Unsur2 pada austenite akan terpecah dan menyebar sehingga membentuk martensite. Proses ini dikenal dengan strain induced martensite.

\section{KESIMPULAN DAN SARAN}

\section{A. Kesimpulan}

Setelah proses penempaan pada penampang pisau B1 nilai kekerasan tertinggi yang didapatkan adalah sebesar 519 HV pada titik ke 2, dan nilai kekerasan terendah sebesar $236 \mathrm{HV}$ pada titik ke 8 . Pada permukaan pisau B1 didapatkan nilai kekerasan tertinggi sebesar $383 \mathrm{HV}$ pada titik ke 1 dan nilai kekerasan terendah sebesar 264 HV pada titik ke 2. Sedangkan pada penampang pisau B2 didapatkan nilai kekerasan tertinggi sebesar $499 \mathrm{HV}$ pada titik ke 1, dan nilai kekerasan terendah sebesar 349 HV pada titik ke 7. 
Sedangkan pada permukaan pisau B2 didapatkan nilai kekerasan tertinggi sebesar $471 \mathrm{HV}$ pada titik ke 10, dan nilai kekerasan terendah sebesar 356 HV pada titik ke 6. Pisau B2 memiliki nilai kekerasan rata2 yang lebih tinggi dibandingkan dengan pisau B1.

Hasil pengamatan struktur mikro menunjukan ukuran butir yang terbentuk setelah proses penempaan lebih kecil dan halus. Batas antara material yang berbeda tetap terlihat dan tidak berdifusi antara satu dengan yang lainnya. Fase yang terbentuk adalah pearlite, ferrite, dan martensite tempered.

Pola yang terbentuk pada permukaan merupakan perbedaan material yang menjadi satu kesatuan pada saat berdifusi antara lapisannya. Batas antara material tersebut tetap terlihat secara makro, sehingga membentuk pola pada permukaannya.

Retakan yang terjadi pada permukaan pisau B1 yang dihasilkan berada pada batas material antara baja JIS SUP 9 dan 0,5 CCrMnSi yang disusun membentuk lapisan. Retakan terjadi akibat penumpukan unsur pada batas antar material yang bereaksi dengan udara, sehingga menjadi getas dan tidak mampu menahan gaya tempa yang diberikan.

Volume bahan awal material pada proses difusi antara lapisannya mengalami reduksi yang cukup besar, sehingga tidak dapat dilakukan proses pelipatan pada pembentukan pisau B2.

\section{B. Saran}

Menggunakan material yang berbeda dalam membentuk pisau dengan metode pattern welding.

Melakukan penelitian mengenai temperatur difusi antara lapisan material yang berbeda pada pembentukan pisau.

Menggunakan tungku pemanasan yang lebih dapat di kontrol temperaturnya.

\section{DAFTAR PUSTAKA}

[1] F. Farzin and Fard, "Damascus Steel," 2011.

[2] D. T. Peterson, H. H. Baker, and J. D. Verhoeven, "Damascus Steel, Characterization of One Damascus Steel Sword,” Mater. Charact., vol. 24, no. 4, pp. 355-374, Jun. 1990.

[3] Balkhaya and Suwarno, "Pengaruh Jenis Bahan dan Proses Pengerasan terhadap Kekerasan dan Keausan Pisau Tempa Manual.”

[4] K. Y. Rasyidy and S. Suwarno, "Pengaruh Temperatur Austenisasi dan Proses Pendinginan Terhadap Strukturmikro dan Proses Pendinginan Baja Paduan 05CCrMnSi,” J. Tek. ITS, vol. 6, no. 2, pp. F309-F312, Sep. 2017

[5] S. A. Jhon, “Introduction to Manufactruing Process," 2000.

[6] J. Hrisoulas, “The Complete Bladesmith,” 1987. 